\title{
Implementation of Enterprise Resource Planning at CV. Dewi Bulan
}

\author{
Putu Putri Wrestra Saridewi ${ }^{a 1}$, I Ketut Gede Darma Putra ${ }^{\text {a2 }}$, I Made Sukarsa ${ }^{\text {a3 }}$ \\ ${ }^{a}$ Information Technology Study Program, Faculty of Engineering, Udayana University, Bukit \\ Jimbaran, Bali, Indonesia, phone. (0361) 701806 \\ e-mail: ${ }^{1}$ putriwrestra@gmail.com, ${ }^{2}$ ikgdarmaputra@unud.ac.id, ${ }^{3}$ sukarsa@ee.unud.ac.id
}

\begin{abstract}
Abstrak
Saat ini perkembangan teknologi informasi sangat pesat, yang memungkinkan banyak perusahaan menggunakan teknologi informasi terkini untuk mendukung kelancaran bisnis perusahaan. CV. Dewi Bulan merupakan usaha kecil menengah (UKM) yang memproduksi dupa. Permasalahan yang dihadapi CV. Dewi Bulan merupakan proses bisnis yang tidak efisien, kegiatan usahanya masih tercatat secara manual, dokumen terkait penjualan, produksi dan pembelian bahan baku masih ditulis tangan pada formulir di perusahaan dan pembukuan dilakukan sebulan sekali. Dokumen-dokumen ini tidak dapat diakses secara real-time. Masalah ini menyebabkan keterlambatan dalam memproses pesanan pelanggan. Solusi untuk mengatasi permasalahan diatas adalah dengan mengimplementasikan Enterprise Resource Planning, dimana dalam prakteknya ERP dapat mengotomatisasi praktik bisnis dan prosedur bisnis perusahaan. Implementasi ERP menggunakan teknologi yaitu menggunakan Odoo versi 11.0. Metode penelitian ini terdiri dari enam tahapan proses penelitian, yaitu; studi literatur, pengumpulan data, pengolahan data, pemodelan aplikasi, pengujian dan implementasi sistem, serta kesimpulan dan saran. Tahap akhir dalam penelitian ini adalah melakukan survei dengan kuesioner UAT dan skala Likert untuk menilai tingkat kepuasan pengguna aplikasi Odoo. Hasil kuesioner didominasi oleh penilaian "Puas", hal ini menunjukkan bahwa proses perbaikan bisnis yang dilakukan dapat diterima dan diterapkan di CV. Dewi Bulan.
\end{abstract}

Kata kunci: Enterprise Resource Planning, Odoo, Proses Bisnis, Skala Likert, UAT.

\begin{abstract}
Nowadays, the development of information technology is very fast, which allows many companies to receive the latest information technology to support the smooth running of the company's business. CV. Dewi Bulan is a small and medium enterprise (UKM) that produces incense stick. The problems that faced by CV. Dewi Bulan is an inefficient business process, its business activities are still manually recorded, documents related to the sale, production and purchase of raw materials are still handwritten on a form in the company and the bookkeeping is done once a month. These documents cannot be accessed in real-time. This problem causes delays in processing of customer orders. The solution to overcome this problem above is to implement Enterprise Resource Planning, where in practice, ERP can automate business practices and company business procedures. ERP implementation uses a technology that is using Odoo version 11.0. This research method consists of six stages of the research process, namely; literature study, data collection, data processing, application modeling, system testing and implementation, also conclusions and suggestions as well. The final stage in this research is to conduct a survey with the UAT questionnaire and a Likert scale to assess the satisfaction level of Odoo application users. The results of the questionnaire were dominated by the assessment of "Satisfied", this indicate that the business improvement process is made were acceptable and applied in CV. Dewi Bulan.
\end{abstract}

Keywords: Business Process, Enterprise Resource Planning, Odoo, Likert Scale, UAT.

1. Introduction

The rapid development of information technology nowadays allows many companies to receive the latest information technology to support the smooth running of a business. 
Information technology is no longer considered only as a compliment, but a determinant of implementing company goals or strategies. This causes the emergence of a new challenge for the company to provide a system of information system that can integrate existing and necessary information. The application of information technology can provide added value to the company and affect a company's confidence in competing with other companies.

$\mathrm{CV}$. Dewi Bulan is a business engaged in the production of local traditional Balinese incense sticks. CV. Dewi Bulan's key business processes, namely sales, procurement, and production. In running the business process, CV. Dewi Bulan has encountered many problems, such as inefficient business processes and manual or conventional recording. Documents related to the sale, production, and procurement of goods are still handwritten on the company's form. The document cannot be accessed directly. These problems can cause constraints in the production process for customer orders because raw materials are not always available. The production process can be started by adjusting the availability of raw materials in the warehouse. Business processes that are carried out conventionally have weaknesses that can cause an error in the reporting process, resulting in the company experiencing errors in decision making [1]. The problems experienced will harm company performance [2]. The solution that can be used to overcome these problems is to implement an ERP system in the company's business processes. The use of an ERP system can integrate business processes and be a solution for manual recording which has been a problem in CV. Dewi Bulan [8]. The use of an ERP system is also expected to help companies to manage the recording of sales documents, and to procure raw materials on a regular basis as well as the production of existing information in the company to carry out a more efficient and more accurate decision-making process.

Enterprise Resource Planning (ERP) is an integrated computing system that automates information, material flows, and resources into one database [9]. Implementing ERP itself will encounter many problems, such as installing an ERP system that is expensive and difficult because it has a high complexity, requires high accuracy, and a long time to input data into the system. On the other hand, CV. Dewi Bulan is classified as a small and medium-sized enterprise that requires minimal cost. Therefore, to implement the ERP system in CV. Dewi Bulan, the Odoo Community software version 1.0, an open-source and web-based ERP system will be employed.

Odoo is an open source-based ERP software formerly known as OpenERP. Odoo software is used as an alternative software which features are needed by the company. Using Odoo software is in great demand by companies that need an integrated system at a low cost. Odoo software offers an excellent opportunity to reduce costs and improve company business processes, especially for small and medium-sized enterprise, which usually have limited costs and human resources [11]. Based on the problems that exist in CV. Dewi Bulan, currently requires an integrated information system that can be accessed in real-time. The information system that are used is Enterprise Resource Planning (ERP). The ERP system is expected to help companies manage recording sales, production, and procurement of raw materials regularly and accelerate the flow of information available to the company to carry out a faster and more precision decision-making process.

Many kinds of research on ERP implementation in various fields have been carried out, one of which is the research conducted by Bagas Ananta Prakosa in 2017. This study discusses the implementation of ERP at UD. Morodadi aims to solve problems whose business processes take a long time to analyse information to develop company performance. This research improves business processes with Business Process Management. Implementing new business processes is carried out using the Odoo application version 9.0 on the Sales, Purchase, Manufacturing, HR, Warehouse and Accounting modules. The results of this study help to integrate all information owned by the company, discuss information flows and improve data accuracy [3].

Andi Sofia Kirana conducted further research on ERP system implementation in 2017. This study discusses ERP implementation at UD. Mutiara Textile aims to integrate all information owned by the company using ERP. The ERP implementation process uses the Odoo version 8.0 application on the Sales, Purchase, Warehouse and Accounting modules. The result of this study is an increase in efficiency in the company's business processes [4].

Further research on ERP implementation was also conducted by Andri Prastyo in 2016. This study discusses ERP implementation at PT. MTE aims to integrate existing divisions in the company so that there are no errors in the transfer of information flow to run more 
effectively and efficiently. The ERP implementation process uses the Odoo version 8.0 application on the Sales, Purchase, Manufacturing, Warehouse and Accounting modules. The research produces an ERP system that helps integrate all the company's business processes [5].

\section{Research Methodology}

The research method describes the stages of each process carried out in research. The research method used in this research is divided into six phases: literature study, data collection, data processing, implementation of the Odoo application, testing the Odoo system, and drawing conclusions and suggestions. An overview of the research method flow can be seen in Figure 1.

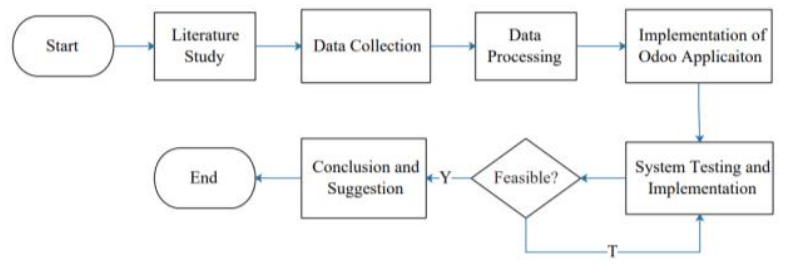

Figure 1. Research Methodology Chart

Figure 1 is the flow of ERP implementation research methods on the CV. Dewi Bulan using the Odoo application. The research method used in this research is divided into six stages: literature study, data collection, data processing, implementation of the Odoo application, testing the Odoo system, and drawing conclusions and suggestions.

\section{$2.1 \quad$ Literature Study}

The literature study stage was carried out by collecting various theories, methods, or models related to the research carried out, such as ERP, Odoo, UAT and Likert Scale. Literature study can be obtained from various sources such as books, journals, and scientific papers to strengthen the theoretical basis that are examined in this research.

\subsection{Data Collection}

The data collection stage was carried out using two methods, mainly conducting the interview and observation process. Interviewing is a technique used to collect data through direct researchers discussing with respondents to extract information from them [6]. The interview stage is carried out by conducting direct discussion with company managers who work in sales, inventory, purchase, manufacturing and invoicing. Furthermore, observation is an activity carried out by collecting data by directly observing the procedures, processes and problems that exist in each process in the company [7]. Observation is conducted by direct inspection of the business processes, procedures, and problems that hinder the company's business performance.

\subsection{Data Processing}

The data processing stage can be carried out after all the required data has been collected, including data from interviews and direct observations in the field. The data obtained is in the form of the company's ongoing business process flow. Data processing is conducted out by making changes and improvements to the company's ongoing business processes, which are expected to help simplify business processes.

\subsection{Implementation of Odoo Application}

The implementation stage is processing the proposed company's business processes using ERP software, namely Odoo Community 11.0. Implementation with Odoo begins with initial configuration and adjustment of the modules contained in the Odoo application with the proposed business process. 


\subsection{System Testing and Implementation}

The testing phase is performed to determine whether implementing the proposed business process using the Odoo 11.0 application has gone well or vice versa. The testing phase is executed by providing a User Acceptance Test (UAT) questionnaire form to respondents to discover the amount of acceptance of the system implementation.

\subsection{Conclusion and Suggestion}

The conclusion stage is the overall result of this research and answers the addressed problems. Suggestions contain actions that need to be done to develop this research or as a further research reference.

\section{Literature Study}

The following is a literature review related to research on ERP implementation from journals, e-books, and articles.

\subsection{ERP}

According to Monk and Wagner (2001), Enterprise Resource Planning is a software program used by companies to integrate and coordinate information flow in each area of business processes [8]. ERP has two types of software in circulation, proprietary ERP software and open-source software (OSS) ERP. OSS ERP has advantages compared to proprietary software, and it can reduce costs, reduce the level of dependence of a company on a particular vendor, and increase adaptability [9]. According to Ellen Monk and Bret Wagner (2001) in their book entitled "Concepts Enterprise Resource Planning", companies have four main operational functions, Marketing and Sales (M/S), Supply Chain Management (SCM), Accounting and Finance (A/F), and Human Resources [8].

\subsection{Odoo}

Odoo (Open ERP) is an open-source Enterprise Resource Planning application that used to be called Tiny ERP, then changed its name to Open ERP and now has become Odoo. Odoo is a modern and complete ERP application that is distributed open-source in which there are various business application programs such as Sales, Customer Relationship Management, Project Management, Warehouse Management, Manufacturing Management, Finance and Accounting Management, Human Resources Management and others [10]. Odoo uses Python, $\mathrm{XML}$ and JavaScript programming languages and uses PostgreSQL as its database management system [11]. Odoo is organized into a module. Modules are folders with predefined structures containing Python code and XML files [12].

\section{$3.3 \quad$ UAT}

User Acceptance Testing is a testing process for application users to provide documents that will serve as evidence that the developed software can be accepted by endusers of the application [13].

\subsection{Skala Likert}

The Likert Scale derives from Rensis Likert, a psychometric scale commonly used in questionnaires and survey research. Responding to questions on a Likert scale, respondents determine their agreement level with a statement by selecting one of the options [14].

\section{Results and Discussion}

Results and discussion contain Enterprise Resource Planning implementation with the Odoo Community Software Version 11.0, which includes the existing business process flow, and the proposed business process flow and system testing.

\subsection{Existing Business Process}

The existing business process summarizes the business processes that are currently running in CV. Dewi Bulan. 


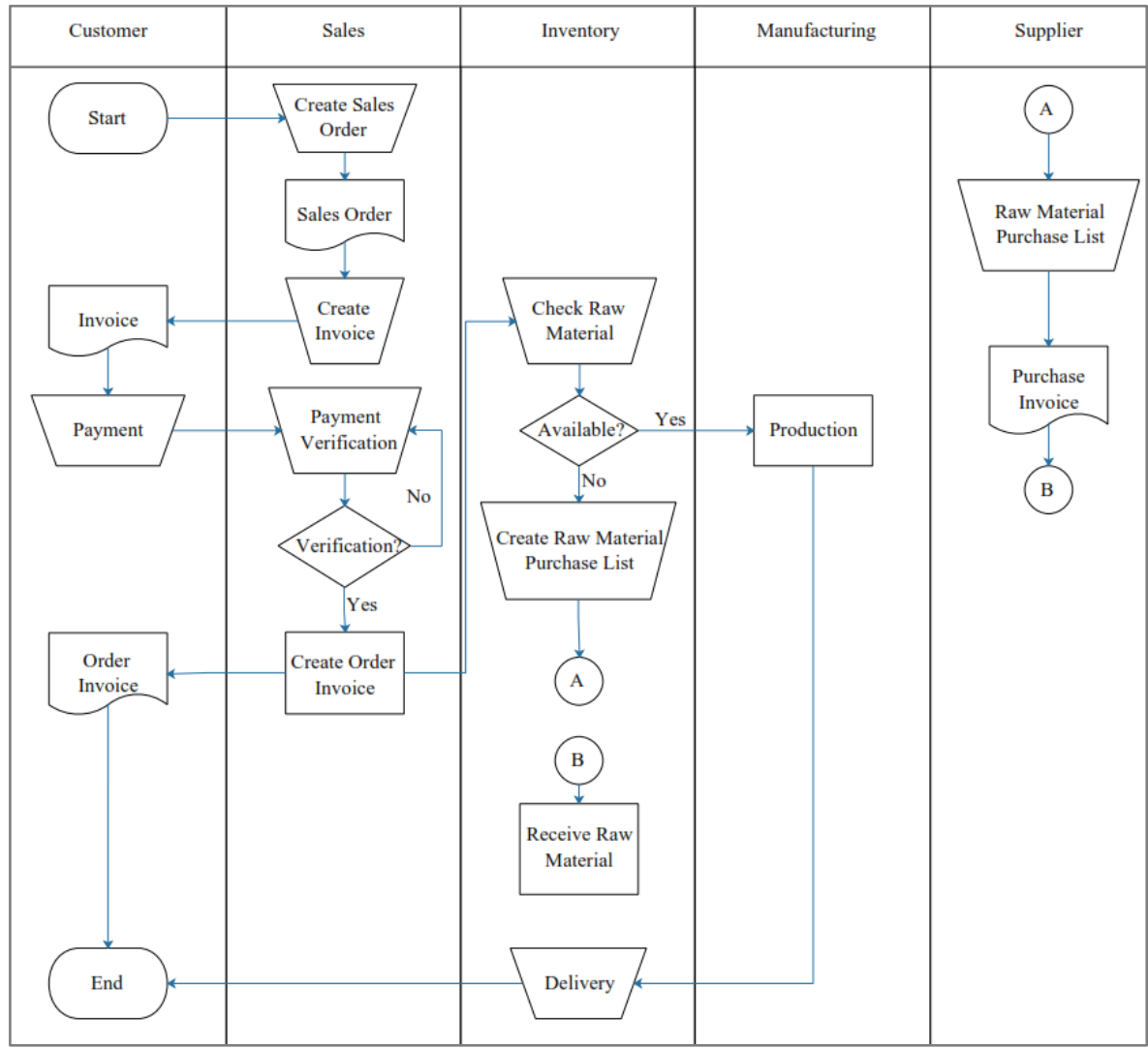

Figure 2. SOP of Existing Business Process

Figure 2 is a business process that is running on CV. Dewi Bulan. The SOP above describes the stages of the company's business process, starting from product sales, inspection of raw materials, procurement of goods, production, and sending goods to customers. The sales department tasks are to draft sales orders, create invoices, verify customer payments, and make sales notes for goods. The Inventory section duty is managing goods in the company's warehouse [15], such as purchasing and receiving raw materials, checking the availability of raw materials for the production process and carrying out shipping goods produced according to orders to customers. The Manufacturing department obligation is to make incense stick production processes based on customer orders.

\subsection{Proposed Business Process}

Improvements to business processes were carried out by adding 2 modules: Purchase and Accounting \& Finance, because there were no such modules in the previous business processes. The description of the proposed complete business process following the application of the Odoo 11.0 system is illustrated in figure 3 


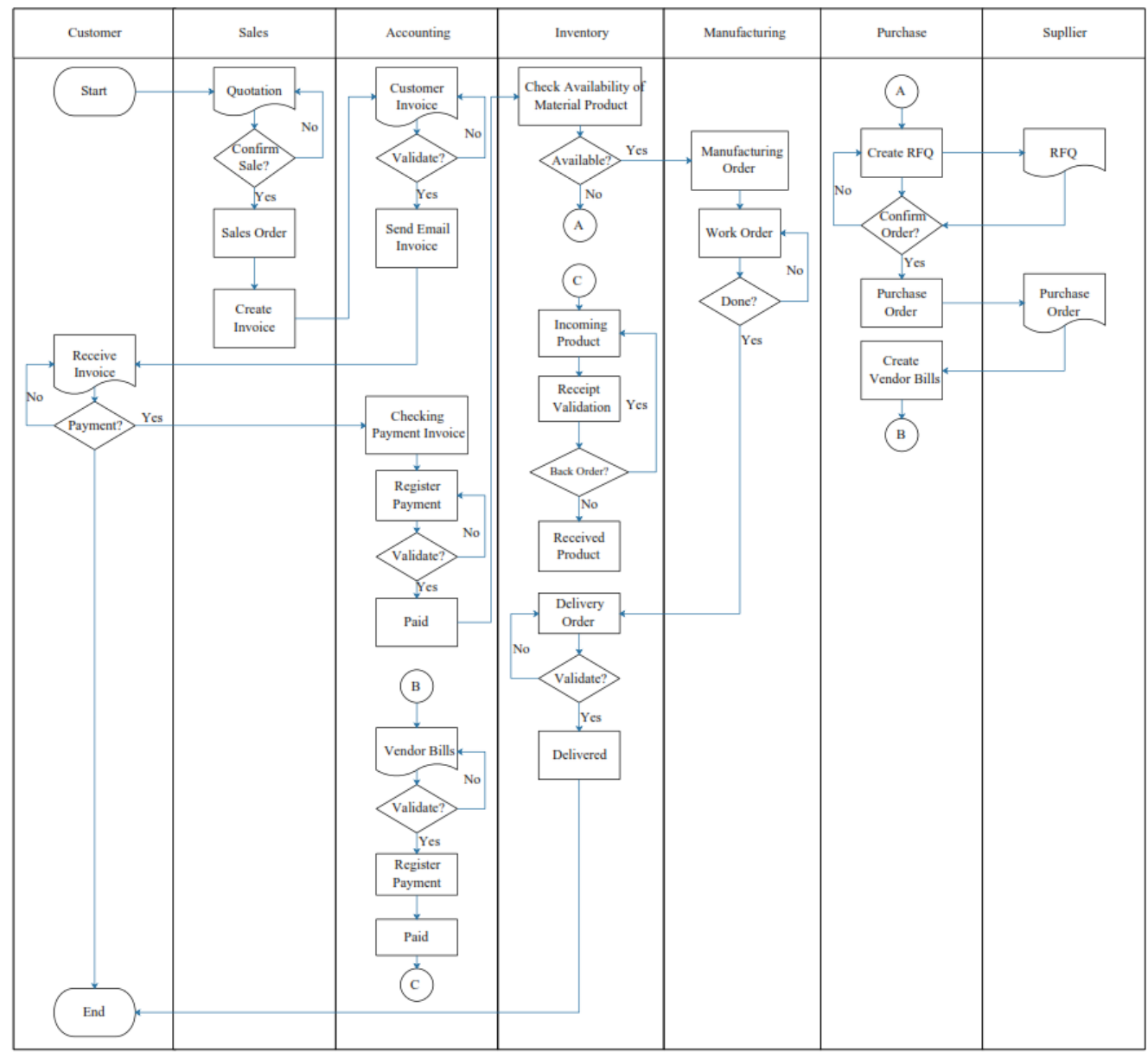

Figure 3. Proposed Business Process

The new overall business process has 3 (three) major processes, namely the sales process, the production process and the procurement process. The sales process here involves two modules: the sales and accounting module; the production process involves the manufacturing and inventory modules, while the procurement process involves the purchase and accounting modules.

\subsection{Implementation of Odoo}

Implementation of new business processes with the Odoo 11.0 application on CV. Dewi Bulan can apply two types of scenarios: when the sales process uses the point of sale (POS) system without the production process and the sales process through pre-order.

\subsubsection{Sales Process Through Pre-order.}

Implementation of sales through pre-order on CV. Dewi Bulan involves Sales, Accounting, Manufacturing, Inventory, Purchasing and Customers. The sales process via preorder will be as follows.

\subsubsection{Quotation}

Quotations are used to enter sales offer data. Quotations are made on the Order $\rightarrow$ Quotation menu, then click the create button. 


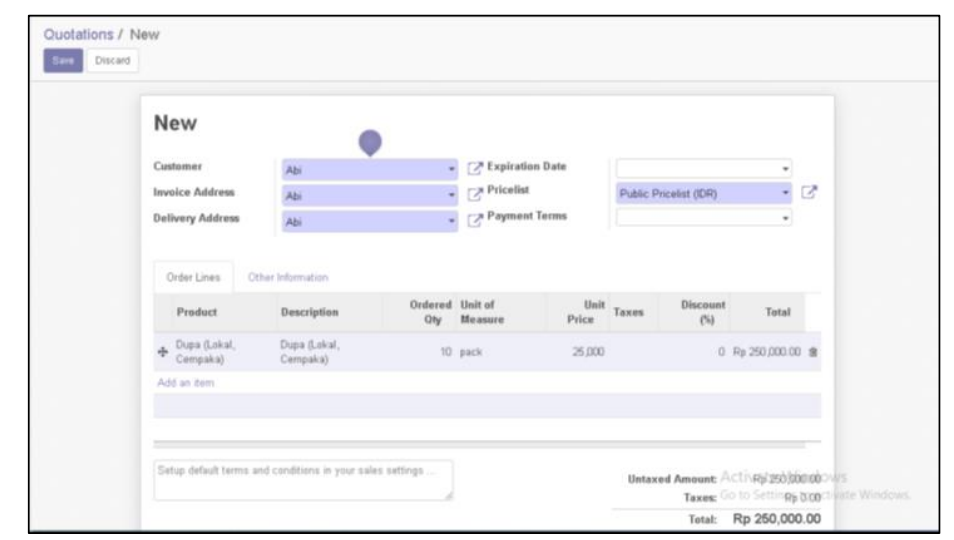

Figure 4. Quotation data display

Figure 4 displays quotations data, where a customer, Abi, orders Cempaka variant local quality incense stick. The sales department ensures the order by sending quotations to the customer via email or printed by clicking the Send by Email button or the Print button.

\subsubsection{Sales Order}

Sales orders are data on purchases of goods by the customer when the quotation has been approved by the Sales Manager.

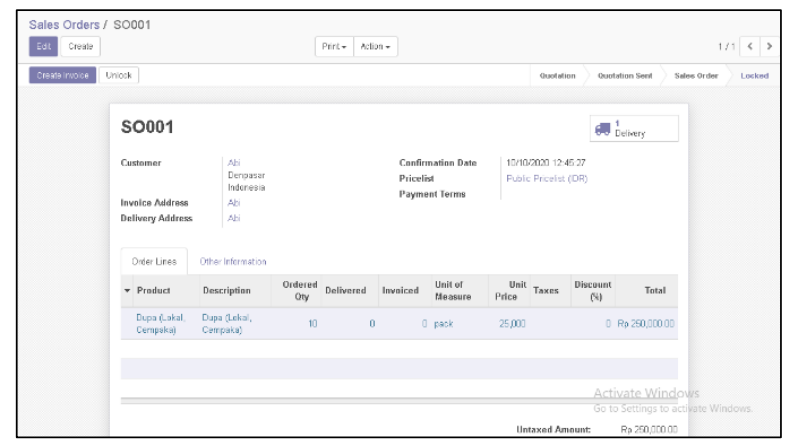

Figure 5. Sales Order

Figure 5 displays quotations after the customer confirms the order, and then the sales user clicks the Confirm Sales button to confirm the order, then the status of the quotations will be changed to Sales Order and Locked. The sales department then creates an invoice by clicking the Create Invoice button.

\subsubsection{Customer Invoice}

Customer Invoice is a bill that must be paid by the customer following the goods ordered. The draft invoice is made after the sales department makes a sales order. The invoice draft will be validated by the accounting manager and then sent to the customer as proof of payment. 


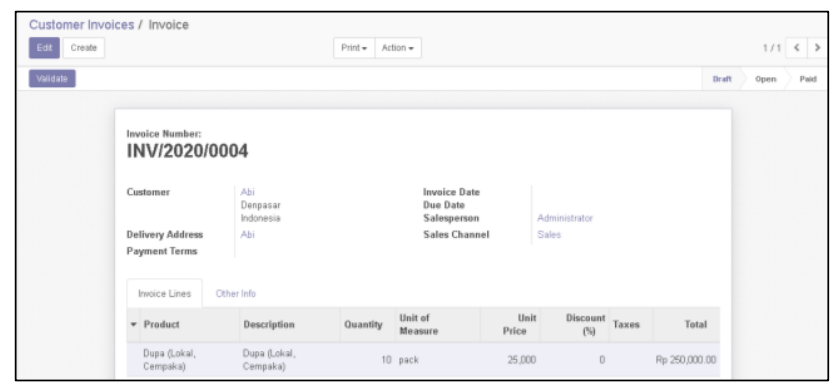

Figure 6. Customer Invoice Validation

Figure 6 is a display of customer invoices. Sales department creates a customer invoice after Sales Order are established. Customer invoices is sent to the accounting department to be validated according to the contents of the data. The accounting department validates the customer invoice and sends the customer invoice to the customer via email.

\subsubsection{Run Scheduler}

The Run Scheduler menu is a menu used to help the Inventory section carry out the procurement or production schedule of goods, based on data reordering rules on company products.

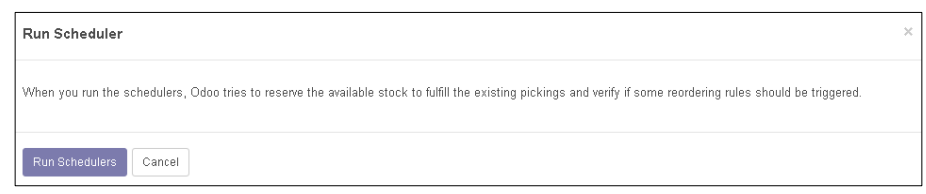

Figure 7. Run Scheduler

Figure 7 displays the run scheduler menu, which will schedule the procurement process and the goods production process in the company.

\subsubsection{Requests for Quotation (RFQ)}

The Requests for Quotation (RFQ) menu is used to help the Purchase section carry out purchasing raw materials.

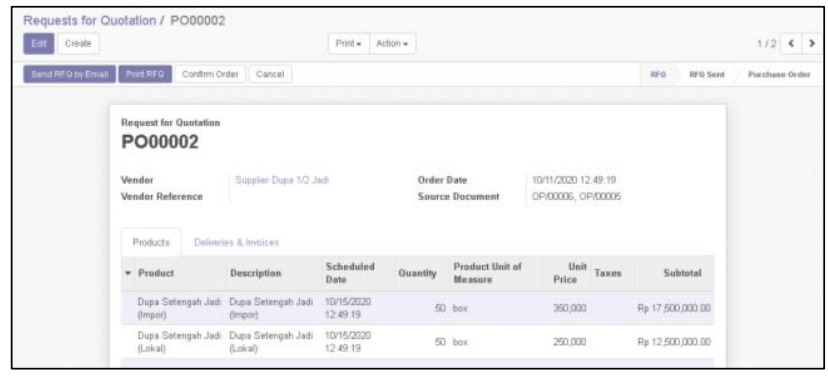

Figure 8. Requests for Quotation (RFQ)

Figure 8 is a display of the Requests for Quotation (RFQ) menu. The Purchase section makes Requests for Quotation (RFQ) for raw materials to be sent to the supplier. The Purchase section then confirms the RFQ following the needs by clicking the Confirm Order button.

\subsubsection{Purchase Order}

The Requests for Quotation (RFQ) document that the Purchase Manager has approved, the status will be changed to a Purchase Order (PO). PO is a document that contains a list of orders for raw materials [16]. Purchase Order (PO) documents will be sent to the supplier to order raw material products. 


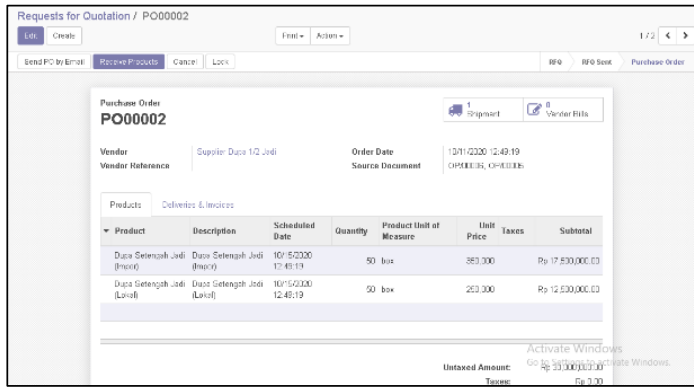

Figure 9. RFQ status display becomes a Purchase Order

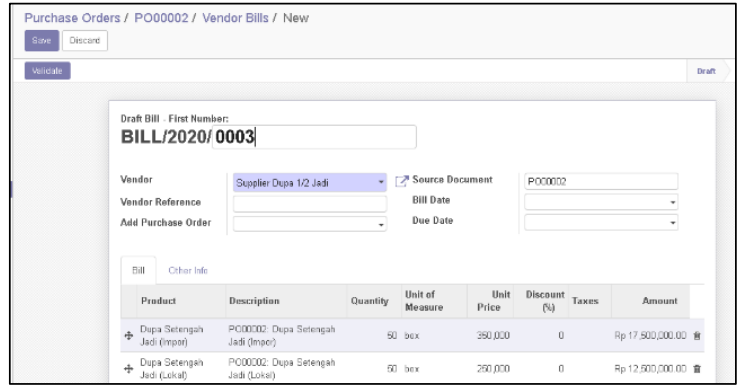

Figure 10. Vendor Bills Validation

Figure 9 displays the confirmed Requests for Quotation, and then the status will be changed to a Purchase Order. The Purchase section then creates a vendor bill, and the accounting section makes payments to the supplier following the Draft Vendor Bills. Figure 10 is the validation process of the bill vendor. The bill vendor validation is carried out by the accounting department. The Accounting Department will then make payments to the supplier according to the invoice.

\subsubsection{Raw Materials Admission}

According to the $\mathrm{PO}$ document to the company, after the company processes the payment, the supplier sends the ordered materials, which the Inventory section will then validate.

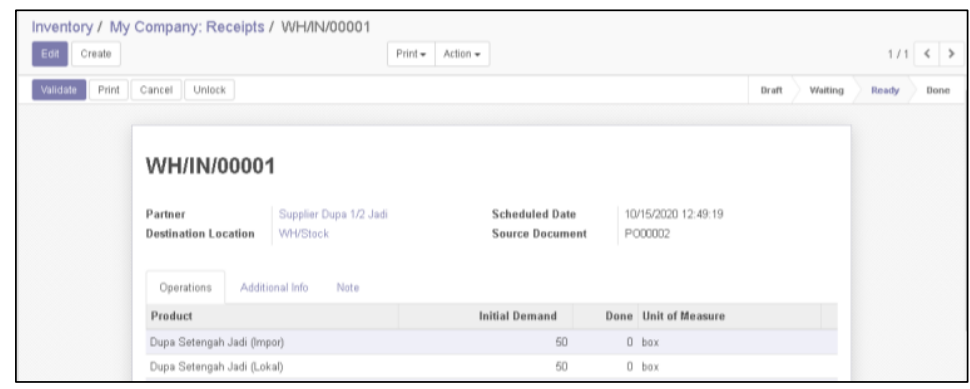

Figure 11. Raw Materials Reception

Figure 11 is a display of the receipt of raw materials. The Inventory Department will receive raw materials sent by the supplier. The Inventory section checks the raw materials sent by the supplier. If the product received is complete, the Inventory section will immediately validate the Receipts form. If a product is received is less or damaged, the Inventory section will process the Back Order.

\subsubsection{Manufacturing Order}

The incense sticks production process is carried out when the raw materials are available. If there are raw materials that are not available, then purchase will be made. 


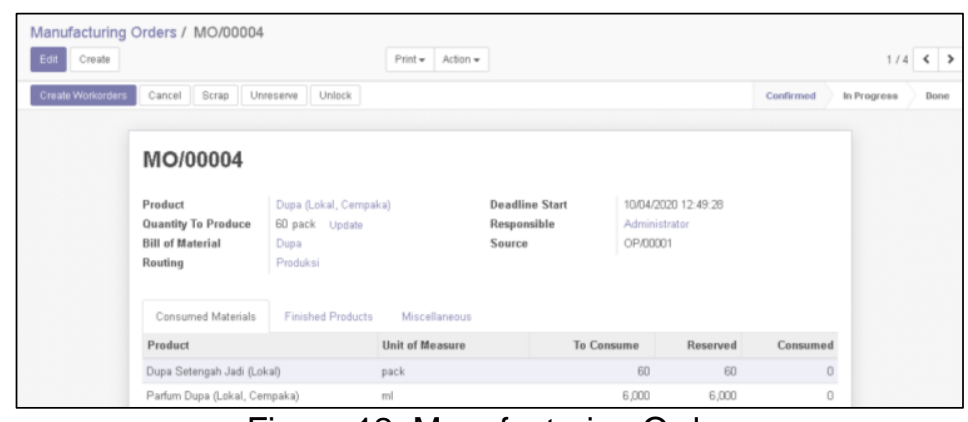

Figure 12. Manufacturing Order

Figure 12 shows an example of a Manufacturing Order document. A manufacturing order is a document that lists production orders based on customer orders. After the Inventory section checks the raw materials for the production process, the Manufacturing section starts the production process by clicking the create work orders button.

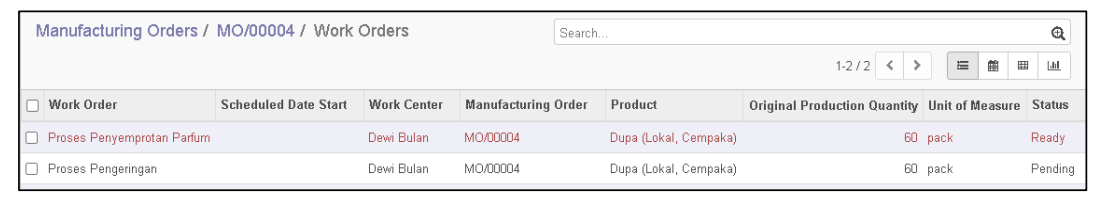

Figure 13. Work Orders

Figure 13 shows a menu of local quality Cempaka incense stick work orders. There are two stages of work orders: first is the spraying process of perfume, and the second is drying the incense. Each work order stage is carried out in sequence. The work order process can be seen in detail by clicking the step. The goods produced will be transferred to the Inventory section for customer delivery when the process is completed.

\subsubsection{Delivery Order}

The Inventory section carries out product delivery to customers if the product stock ordered is still available in the warehouse or after going through the production process when the product stock has run out. Product delivery is carried out on the Inventory $\rightarrow$ Delivery Order $\rightarrow$ To Do menu, and then the Inventory section selects the name of the customer or sales order document from the Delivery Order list.

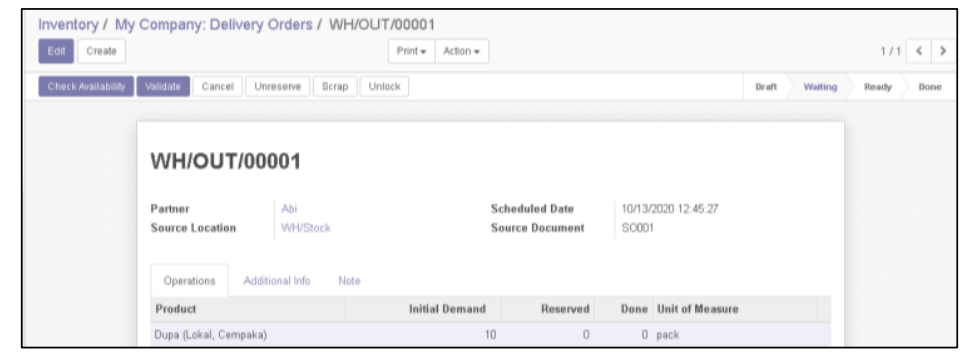

Figure 14. Check availability delivery order

Figure 14 displays the product checking process, which is carried out by the Inventory section. Ready-to-send products can be checked by clicking the check availability button. If the product is available, the Inventory section can deliver it to the customer.

\subsubsection{Sales Process through Point of Sale (POS)}

The point of sale (POS) system on the Odoo application involves Sales Users and Customers. POS is a company's business area that in direct contact with customers so that an 
improvement in this business unit can affect customer satisfaction [17]. The sales process flow through the Point of sale (POS) system will be explained in figure 15 and 16.

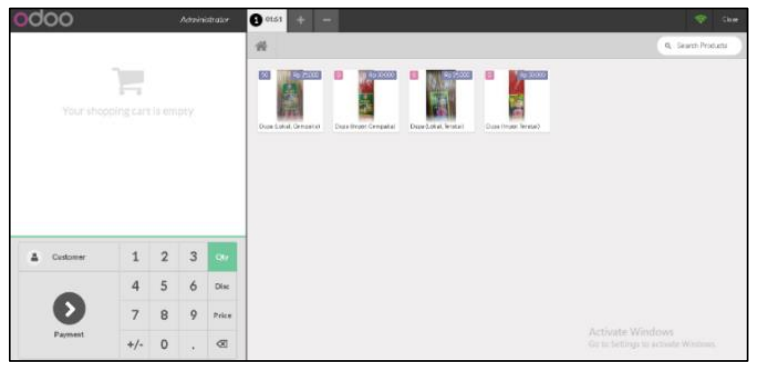

Figure 15. POS System Display

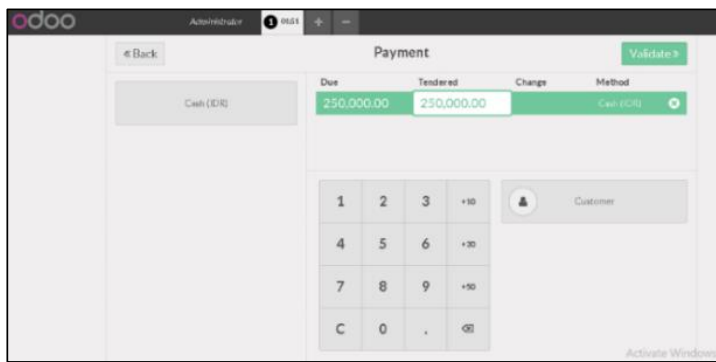

Figure 16. Payment Process Display

Figure 15 is displays the POS system, which appears after the Sales User clicks on the new session button. POS system can be used to process sales transactions such as cashiers in general, where the POS system is integrated with the inventory section to see the goods and the number of stock items sold by the company. Figure 16 is a display of the payment process in the POS system. The Sales User carries out the payment process by entering the amount of money paid by the customer. The system will automatically carry out the calculation process. If the amount of money paid by the customer is in accordance with the total purchase amount, there will be no change, but if there is the remaining change, it will appear in the Change column, which is the amount of money that must be returned to the customer. The next step is validating sales by the Sales department by clicking the Validate button and printing the customer invoice.

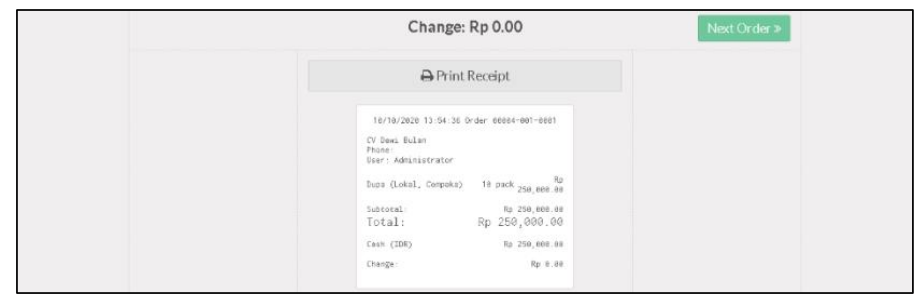

Figure 17. Invoice POS Display

Figure 17 shows invoices in the POS system. User can print it by clicking Print Receipt button. Sales department can make other sales by clicking the next order button, and the system will return to the initial view of the POS system. To end the Point of Sales system, click the close button

\subsection{Odoo System Testing}

This research trial was conducted on 17 respondents consisting of 16 company employees and 1 student. Odoo system testing is done by providing a User Acceptance Test (UAT) questionnaire form to respondents to determine the amount of acceptance of the system implementation. The test document contains 8 classifications of questions comprising 34 statements. The test uses a Likert scale of 1 to 5 , whose results are shown in Table 1 . The questionnaire is a data collection technique that contains a list of questions to understand respondents to several variables considered in ERP implementation [18].

The formula that will be used to calculate the results of the User Acceptance Test (UAT) questionnaire:

Maximum score $=$ Total Number of Respondents $x$ Highest Likert Score 
Formula 1 is a formula to determine the maximum score. The calculation of the maximum score is done to determine the Index score (\%) later. The maximum score is obtained by multiplying the total number of respondents by the highest Likert score.

Index $(\%)=\left(\frac{\text { Total scale score }}{\text { Maximum score }}\right) \times 100$

Formula 2 is a formula to determine the index score (\%). The index score (\%) calculation is conducted by adding up all the existing scale score and then dividing by the maximum score, after which it is multiplied by 100 . The index score (\%) obtained is then entered into several categories [19].

Table 1. Index Score Category (\%)

\begin{tabular}{|c|c|c|c|c|c|}
\hline Index $(\%)$ & $0 \%-19 \%$ & $20 \%-39 \%$ & $40 \%-59 \%$ & $60 \%-79 \%$ & $80 \%-100 \%$ \\
\hline Category & Very Dissatisfied & Dissatisfied & Neutral & Satisfied & Very Satisfied \\
\hline
\end{tabular}

Table 1 is a table of index score ranges (\%). The index value score (\%) starts from $0 \%$ $-19 \%$ with a very dissatisfied category. Index score (\%) from $20 \%-39 \%$ in the dissatisfied category, $40 \%-59 \%$ in the neutral category, $60 \%-79 \%$ in the satisfied category, and index score $(\%)$ from $80 \%-100 \%$ in the very satisfied category [19].

Table 2. Result Questionnaire User Acceptance Test (UAT)

\begin{tabular}{|c|c|c|c|c|}
\hline $\begin{array}{c}\text { Question } \\
\text { Classification }\end{array}$ & Question & Total & Index & Category \\
\hline \multirow{3}{*}{$\begin{array}{l}\text { Application } \\
\text { Display }\end{array}$} & Odoo app is easy to use & 60 & $70 \%$ & Satisfied \\
\hline & Attractive application display & 64 & $75 \%$ & Very Satisfied \\
\hline & The language used is easy to understand & 68 & $80 \%$ & Satisfied \\
\hline \multirow{2}{*}{$\begin{array}{c}\text { User } \\
\text { Management }\end{array}$} & Each user has their own access rights & 68 & $80 \%$ & Very Satisfied \\
\hline & User data security is guaranteed & 71 & $83 \%$ & Very Satisfied \\
\hline \multirow{5}{*}{ POS } & POS users can close and post sales & 19 & $76 \%$ & Satisfied \\
\hline & Payment type can be specified & 21 & $84 \%$ & Very Satisfied \\
\hline & $\begin{array}{l}\text { The name of the customer who is shopping can } \\
\text { be entered }\end{array}$ & 20 & $80 \%$ & Very Satisfied \\
\hline & Invoices can be easily printed & 22 & $88 \%$ & Very Satisfied \\
\hline & Can check sales report on POS & 18 & $72 \%$ & Satisfied \\
\hline \multirow{5}{*}{ Sales } & Can easily make quotations and sales orders & 19 & $76 \%$ & Satisfied \\
\hline & $\begin{array}{l}\text { Quotation and Sales Order can be sent via email } \\
\text { to customers }\end{array}$ & 22 & $88 \%$ & Very Satisfied \\
\hline & Draft customer invoices can be made easily & 22 & $88 \%$ & Very Satisfied \\
\hline & Can create new customers & 20 & $80 \%$ & Very Satisfied \\
\hline & Can check sales report & 19 & $76 \%$ & Satisfied \\
\hline \multirow{5}{*}{ Purchase } & $\begin{array}{l}\text { Making RFQ can it be made automatically if there } \\
\text { is a shortage of stock? }\end{array}$ & 17 & $68 \%$ & Satisfied \\
\hline & Can do back orders & 17 & $68 \%$ & Satisfied \\
\hline & Purchase Orders can be sent via email & 22 & $88 \%$ & Very Satisfied \\
\hline & Can make vendor bills & 22 & $88 \%$ & Very Satisfied \\
\hline & Can view raw material purchase reports & 18 & $72 \%$ & Satisfied \\
\hline \multirow{4}{*}{ Manufacturing } & Can control the production process well & 12 & $48 \%$ & Satisfied \\
\hline & Creating Routings & 16 & $64 \%$ & Satisfied \\
\hline & Operation Making & 16 & $64 \%$ & Satisfied \\
\hline & Making Bills of Materials & 15 & $60 \%$ & Satisfied \\
\hline
\end{tabular}




\begin{tabular}{|l|l|c|c|c|}
\hline \multirow{5}{*}{ Inventory } & Making Manufacturing Orders & 17 & $76 \%$ & Satisfied \\
\cline { 2 - 5 } & Goods Production Report & 13 & $52 \%$ & Satisfied \\
\hline \multirow{5}{*}{ Invoicing } & Receipt of Raw Materials from suppliers & 20 & $80 \%$ & Very Satisfied \\
\cline { 2 - 5 } & Receipt of finished goods & 20 & $80 \%$ & Very Satisfied \\
\cline { 2 - 5 } & Delivery of ordered goods to customers & 20 & $80 \%$ & Very Satisfied \\
\cline { 2 - 5 } & Making Reordering rules & 17 & $68 \%$ & Satisfied \\
\cline { 2 - 5 } & Product move report & 21 & $84 \%$ & Very Satisfied \\
\hline \multirow{3}{*}{} & Customer Invoice Validation & 20 & $80 \%$ & Very Satisfied \\
\cline { 2 - 5 } & Vendor Bills Validation & 20 & $80 \%$ & Very Satisfied \\
\cline { 2 - 5 } & Invoicing report & 17 & $68 \%$ & Satisfied \\
\hline
\end{tabular}

Table 2 results from the calculation of the User Acceptance Test (UAT) questionnaire for 17 respondents. The average of the results of the questionnaire is described in table 3 .

Table 3. Questionnaire UAT Final Score

\begin{tabular}{|c|c|c|c|}
\hline Question Classification & Total Score & Index (\%) & Category \\
\hline Application Display & 192 & $75 \%$ & Satisfied \\
\hline User Management & 139 & $81 \%$ & Very Satisfied \\
\hline POS & 100 & $80 \%$ & Very Satisfied \\
\hline Sales & 102 & $81,6 \%$ & Very Satisfied \\
\hline Purchase & 96 & $76,8 \%$ & Satisfied \\
\hline Manufacturing & 89 & $59,3 \%$ & Neutral \\
\hline Inventory & 98 & $78,4 \%$ & Satisfied \\
\hline Invoicing & 57 & $76 \%$ & Satisfied \\
\hline
\end{tabular}

Table 3 is the final score of the User Acceptance Test (UAT) questionnaire, where the classification questions for Application Display, Purchase, Inventory and Invoicing are in the Satisfied category. User Management, POS, and Sales question classifications are in the Very Satisfied category. The classification of manufacturing questions has a neutral category.

\section{Conclusion}

Based on the results of the analysis and discussion of the implementation of Enterprise Resource Planning on CV. Dewi Bulan can help companies manage business processes that are still carried out conventionally and are not integrated with each other. ERP implementation on CV business processes. Dewi Bulan uses the Odoo Community 11.0 application and implements 5 modules, namely Sales, Inventory, Purchase, Manufacturing, and Invoicing. Changes that occur in the CV business process. Dewi Bulan only changed business processes that were originally conventional into integrated devices using Odoo. Based on the results of the User Acceptance Test (UAT) questionnaire, it is proven that the ERP implementation uses Odoo 11.0 on CV. Dewi Bulan in terms of Application Display, User Management, POS, Sales, Purchases, Inventory and Invoicing has met user satisfaction in the "Satisfied and Very Satisfied" category. Meanwhile, in terms of Manufacturing, it still does not meet user satisfaction because there are some parts of the application that cannot be understood. by the user.

\section{Reference}

[1] E. Yulianti, A. A. K. O. Sudana, and N. M. I. M. Mandenni, "Perancangan Sistem Informasi Manajemen Rumah Sakit Modul Farmasi," Lontar Komputer: Jurnal Ilmiah Teknologi Informasi, vol. 6, no. 2, pp. 96-107, 2015.

[2] M. Daniel, "Enterprise systems : An emerging technology for Papua New Guinea 
universities," Contemporary PNG Studies: DWU Research Journal, no. May 2016, pp. 18-33, 2017.

[3] B. A. Prakosa, "Implementasi dan Konfigurasi Free Open Source Enterprise Resource Planning (ERP) Odoo 9.0 c: Studi Kasus: UD. Morodadi," 2017.

[4] A. Sofia Karina and A. S. Karina, "Konfigurasi Sistem ERP Odoo pada Wholesale Tekstil: Studi Kasus UD. Mutiara Textile," p. 209, 2016.

[5] A. Prastyo, R. Rispianda, and C. Nugraha, "Rancangan Sistem Informasi Terintegrasi di PT. MTE Berbasis Sistem Enterprise Resource Planning Menggunakan Software Odoo," Reka Integra, vol. 4, no. 1, pp. 134-145, 2016.

[6] P.T. Eka Yudhi Pratama;l Made Darma Susila; I Gede Harsemadi, "Animasi 2D Interaktif Cerita Rakyat Asal Mula Selat Bali," Eksplora Informatika, vol. 1, no. 1, pp. 1-12, 2015.

[7] D. Mahdiana, "Pengadaan Barang Dengan Metodologi Berorientasi Obyek: Studi Kasus PT . Liga Indonesia," Jurnal TELEMATIKA, vol. 3, no. 2, pp. 36-43, 2016.

[8] W. Monk, Ellen; Bret, Concepts in enterprise resorce planning, vol. 40, no. 6. 2001.

[9] P. Wuri Handayani and U. Hariyaty, "Analisis Fungsionalitas Open Source Software ERP Untuk Pengembangan Modul Pembelajaran ERP," Journal of Chemical Information and Modeling, vol. 53, no. 9, pp. 118-125, 2017.

[10] Y. Indanea, R. R. Saedudin, and R. W. Witjaksono, "Implementasi Sistem Produksi Berbasis Odoo Pada Pt . Primarindo Asia Infrastructure Tbk Dengan Metodologi Asap Implementation of Odoo - Based Production System With Asap Methodology At Pt . Primarindo Asia Infrastructure Tbk," proceeding Engineering, vol. 3, no. 2, pp. 31953201, 2016.

[11] C. A. Lestari, "Implementasi Odoo Dengan Modul Accounting and Finance di SD Islam Tunas Mandiri," Jurnal Informatika Terpadu, vol. 3, no. 1, pp. 1-6, 2017.

[12] C. R. Suwu, I. M. Sukarsa, and I. P. A. Bayupati, "Pengembangan Sistem HRM Terintegrasi Dengan Pendekatan ERP," Merpati, vol. 4, no. 3, pp. 259-270, 2016.

[13] M. A. R. Abdillah, A. A. Widodo, and R. Hariyanto, "Penerapan Augmented Reality Pada Aplikasi Pembelajaran pancasila," Seminar Nasional Teknologi Informasi dan Komunikasi STI\&K, vol. 4, no. 1, pp. 217-221, 2020.

[14] W. Indy, A. A. K. C. Wiranata, and K. A. Purnawan, "Pengembangan Game Castle Defense 'Jagaraga' pada Platform Android," Merpati, vol. 3, no. 1, pp. 48-57, 2015.

[15] A. A. I. A. D. Purnamaningrat, I. M. Sukarsa, and N. M. I. M. Mandenni, "Perancangan Sistem Informasi Manajemen Rumah Sakit Modul Sarana dan Prasarana," Lontar Komputer: Jurnal Ilmiah Teknologi Informasi, vol. 6, no. 2, p. 73, 2015.

[16] D. D. Antari, I. M. Sukarsa, and I. P. A. Bayupati, "Implementasi Proses Bisnis pada Perusahaan Retail Menggunakan Software Adempiere," Merpati, vol. 2, no. 1, pp. 4349, 2016.

[17] D. K. Mahardika, I. M. Sukarsa, and P. W. Buana, "Pemodelan ERP pada Perusahaan Manufaktur dengan Software OpenERP7.0," Merpati, vol. 2, no. 1, pp. 18-24, 2016.

[18] I. P. A. A. P. Putra, I. M. Sukarsa, and I. P. A. Bayupati, "Audit Ti Kinerja Manajemen Pt. $X$ Dengan Frame Work Cobit 4.1," Lontar Komputer: Jurnal Ilmiah Teknologi Informasi, vol. 6, no. 1, pp. 13-24, 2015.

[19] U. Raharja, E. P. Harahap, and R. E. C. Devi, "Pengaruh Pelayanan dan Fasilitas pada Raharja Internet Cafe Terhadap Kegiatan Perkuliahan Pada Perguruan Tinggi," Jurnal Teknoinfo, vol. 12, no. 2, p. 60, 2018. 